\title{
PECULIARITIES OF DIGITALIZED LEARNING PROCESS ORGANISATION IN THE LEARNING MANAGEMENT SYSTEMS
}

\author{
Oleksandr Bazeliuk, \\ $\mathrm{PhD}$ in Education, DSc Student at the Institute of Vocational Education and Training of NAES of Ukraine \\ http://orcid.org/0000-0002-3206-2287 \\ e-mail: o.bazeliuk@ukr.net
}

\begin{abstract}
The author reviews the peculiarities of digitalized learning process organisation in the hardware and software environment of learning management systems in the context of vocational education and training. The author notes the complexity of the transition to the Industry 4.0 and mentions the risks connected with the named process in the vocational education and training. In such conditions it is important to develop effective models of public and private partnership, to decentralize administration and financing and, above all, to assure the vocational education and training quality. Using the software and hardware complexes of learning management systems is one of the means able to ensure the implementation of such tasks and to avoid risks in the sphere of vocational education and training. At the same time the learning process taking place in such an environment becomes digitalized, which, on the one hand, gives it additional advantages (easy access to training data regardless of time and place, individualisation of students' learning paths, broad multimedia resources, etc.) and, on the other hand, requires solving complex tasks in distance courses designing. The author focuses on the methodology of distance courses designing, so it is very important for vocational education and training institution to ensure the realisation of the following five main components: regulatory, financial, technical, personnel, teaching and methodological support. It is emphasised that distance course designing becomes the most important aspect of implementing the modern digitalized learning process. The structure of creative group in distance courses designing is grounded, which comprises: a specialist in the relevant vocational sphere, specialist in distance learning, technical specialist (system administrator or distance courses programmer) and digital content designer. It is underlined that assigning the task to design a distance course only to a teacher is unacceptable. At the same time, the process of learning digitalization in an education institution cannot be limited to introducing a learning management system.
\end{abstract}

Key words: vocational education and training, digitalization, digitalized learning process, digital learning environment, learning management system, distance course.

Introduction. The process of the world society transition to the Industry 4.0 has caused the need for fundamental modernization of all spheres of human life, including vocational education and training. At the same time researchers point out that there are a number of systemic problems in Ukraine which complicate this process greatly. Among the main problems researchers distinguish the following: low attractiveness and accessibility of vocational education and training; vocational education and training institutions' educational process provision with qualified and motivated teaching and other staff; disparity of training content with the modern requirements of labour market concerning the level of skilled workers' professional competency; creation of modern learning environment, the system of internal and external quality assurance of vocational education and training, etc. (Radkevych, et al, 2018).

The tasks of assuring the quality of education, decentralizing administration and financing, creating effective models of public and private partnership has appeared on the agenda (Ministry of Education and Science of Ukraine, 2018). 
Materials. V. Bykov and A. Gurzhii works are dedicated to enlightening the conceptual bases of informatisation and digitalization of education. A wide range of problems concerning the use of modern electronic means in the learning process of vocational education and training institution are enlightened in the O. Spirin, A. Kalenskyi, M. Pryhodii works. Methodological aspects of distance vocational learning are disclosed in a number of works by L. Petrenko, $\mathrm{S}$. Kravets. The use of electronic education resources and creating SMART-complexes for vocational education and training are revealed in the O. Humennyi, A. Kononenko, L. Lypska works.

The article aim is to ground the components of distance learning process in the digital environment of learning management system, in particular, the distance courses designing for vocational education and training.

Methods. The following methods were used to analyse the research phenomenon: comparison of scientific facts and generalisation of educational experience with extrapolation to the theory and methods of vocational education and training of the analysed research statements and empirical concepts; study of the documents and results of vocational teachers' activity, pedagogical and self-observation etc.

Results and discussion. One of the most important means that has great potential in solving these problems is the skilled workers' distance vocational learning, which is based on modern digital technologies, including specialized hardware and software complexes - learning management systems. However, the results of a large-scale fundamental study of the methodological foundations of the skilled workers' distance vocational learning conducted by the Laboratory of Distance Vocational Learning of the Institute of Vocational Education and Training of the National Academy of Educational Sciences of Ukraine (Radkevych and Artiushyna eds., 2017; Radkevych, 2018) showed that the major difficulties are the proper organization of the distance learning process, in particular, in terms of ensuring the interoperability among its various participants.

In accordance with the "Regulations on Distance Learning" (Order of the Ministry of Education and Science of Ukraine dated April 25, 2013 No 466), "subjects of distance learning are persons who study (pupil, student, listener), and those who provide the learning process in a distance mode (teaching staff, academic staff, methodists, etc.)" (Ministry of Education and Science of Ukraine, 2013). It is suggested that distance learning technologies in vocational education and training institutions can be used in organising the learning process in the initial vocational training, retraining or in-service training programs, as well as in studying the vocational theoretical disciplines (Ministry of Education and Science of Ukraine, 2013).

As mentioned above modern LMS are complex digital hardware and software complexes that can fully implement almost all aspects of the modern learning process, in particular: assessment of the process of professional competences acquiring by a student; statistics collection, analysing and saving concerning each aspect of the student's activity (group of students, institution as a whole) within the LMS; the ability to set up a complex analysis to ensure the quality of education (BigData basic level), etc.

Distance learning specifics in vocational education and training institution presupposes implementation of vocational and practical training "in a distance mode and/or full-time mode in the form of on-the-job training, different forms of practice, conducted at the workshops, polygons, simulators, racetracks, in education and production units, training enterprises, on the workplaces in the spheres of production and services, etc. or using the distance learning technologies if relevant web resources and access to them are available" (Ministry of Education and Science of Ukraine, 2013), i.e. in a mixed mode (blended learning).

So, learning management systems are not only a didactic tool, but also the core of digital learning environment of a vocational education and training institution. Such a powerful influence on all components of the leaning process transforms not only the ways of interaction between its participants, but, first of all, changes both the composition of participants and their functions. The list of subjects of distance learning process should be supplemented by engineering, technical and additional personnel (system administrators, programmers and other IT specialists, distance learning administrators, engineering and technical staff, etc.).

Involvement of these specialists enables implementation of organizational and pedagogical conditions for distance vocational learning, formulated by S. Kravets (2018). These conditions are grouped into three blocks taking into account regulatory, technical, pedagogical, personal and professional requirements for informatization of education:

- organizational and technical (availability of legal and regulatory support for distance vocational education; availability of a specialized learning management system),

- content and processual (designing and placing modern distance courses in the electronic environment; use of blended learning in the professional training of students and listeners),

- personal and professional (level of students' and listeners' mastering the IT technologies; continuous 
development of teachers' readiness to introduce distance learning technologies).

In the following article we will focus on the content and processual block, because, as the results of our study showed, the greatest problem for vocational education and training institutions is the complexity of the process of distance courses designing and placing.

For learning management systems, for example, for the LMS Moodle, which is the most widespread in Ukraine, the main content unit is a distance course. Distance courses may consist of an unlimited number of topics, but topics themselves cannot exist independently outside the distance course (Bazeliuk, at al., 2018). It is possible to construct the controlled learning paths by configuring the access system to the distance course topics. Due to this, learning management system easily implements the mechanisms of the so-called "guided self-education of students".

It is important to implement the five main components - regulatory, financial, technical, personnel, teaching and methodological support - to accomplish the tasks of distance learning in the vocational education and training institution. All components of distance learning are interconnected and interdependent, and therefore mistakes or lack of implementation of one of the components will significantly affect not only the effectiveness of distance learning, but also the possibility of its functioning. For example, insufficient financial support significantly affects the technical component, complicates the development of teaching and methodological support for distance learning and the educational process as a whole. Problems with staffing will not allow to realize the possibilities of learning management systems to the fullest, which affect the quality of students' learning.

In the context of vocational education and training at the first stage, it is important to ensure a balanced implementation of the first three components, since the personnel, teaching and methodological support depends considerably on the selected learning management system. The peculiarities of choosing the learning management system for vocational education and training are described in detail in O. Bazeliuk article (2016).

As O. Spirin emphasizes "the use of ICT in education can take place in a variety of organizational forms: online courses, online counselling, online trainings, hackathons, webinars, the use of interactive electronic tutorials, electronic virtual laboratories, electronic social networks, visiting interactive science museums, creation of presentations, scientific platforms for communication, international scientific contests, virtual technology parks and others" (Bazeliuk, at al., 2018).

Each of these forms is realised within a concrete distance course. So, distance course is the main content unit in distance learning. Hence, the development of the distance course becomes very important aspect in implementing the distance learning process (Bazeliuk, at al., 2017).

The distance course, in its turn, has four main components: technical; educational and content; educational and processual; multimedia. Today, the task of distance courses designing lies on the teaching staff of the vocational education and training institutions, who independently select the training content, predict and build the students' learning paths, develop the digital content design and, finally, program it by themselves in the learning management system. Such a wide range of tasks cannot be implemented without loss of quality at each stage. It especially concerns the multimedia component that affects the visual design and is perceived by the students first, and the technical component, errors in which can lead to a complete stop of the learning process. Such an approach to distance courses designing is marked by a significant overload of teachers and the need to perform tasks beyond their competence.

Therefore, a group of specialists should be involved in ensuring the quality of distance course content and multimedia filling, the correct didactic organization of the process, the provision of a qualitative visual component, as well as the correct transfer and stable work of a distance course in the learning management system. Taking into account the specifics of the educational process in the vocational education and training institutions, we consider that this group of specialists should consist of: a specialist in the relevant vocational sphere, specialist in distance learning, technical specialist (system administrator or distance courses programmer) and digital content designer.

We consider that the proposed structure of creative group in distance courses designing is able to realize each of the components of the distance course on a high professional level and not only provide didactically correct learning process, but also further improve the distance course under the specific conditions of a vocational education and training institution, update the content, adapt it not only for different groups of students, but also to ensure the implementation of a student-centred approach to the learning process in a vocational education and training institution.

Conclusions. Digital distance learning technologies, in particular, in vocational education and training, are based on the principles of open 
education, are the most advanced promising technologies of its organization and have a decisive impact on the nature and pace of digitalisation of the education system as a whole. The organization of the digital learning process in a vocational education and training institution should be carried out in the environment of learning management systems by a group of specialists consisting of: a specialist in the relevant vocational sphere, specialist in distance learning, technical specialist (system administrator or distance courses programmer) and digital content designer. We consider that it is unacceptable to require from vocational education and training institutions teaching staff to design distance courses without the participation of the proposed group of specialists. The process of learning digitalization in an institution cannot be limited only by introducing only learning management systems. The digitalisation of vocational education and training is not only filling it with modern electronic means, but, first of all, the appearance of new opportunities for its global structural analysis and the selection of vectors of development based on it, which either significantly accelerate the skilled workers training, or will enable students to acquire a higher level professional competence. Thus, in our opinion, research on the introduction of SMART technologies, electronic management systems and automated analytics in vocational education and training institutions becomes promising.

\section{List of references}

Базелюк, О. В., 2016. Особливості вибору систем дистанційного навчання для професійної освіти. [online] Методичні засади підвищення кваліфікації педагогічних працівників системи професійної освіти. Доступно: <http:/ /lib.iitta.gov.ua/107095/> [Дата звернення 17 Квітень 2019].

Базелюк, О. В., Каленський, А. А., Кравець, С. Г. та ін., 2017. Підготовка педагогічних працівників професійно-технічних навчальних закладів до дистаниійного навчання кваліфікованих робітників. Київ: Ін-т проф.-тех. освіти НАПН України.

Базелюк, О. В., Спірін, О.М., Петренко, Л.М., Каленський, А.А. та ін., 2018. Технологї̈ дистанційного професійного навчання: методичний посібник. Житомир: Полісся.

Верховна Рада України. Законодавство України, 2013. Про затвердження Положення про дистаниійне навчання 25.04.2013 № 466. [online] (Останнє оновлення 21 Серпень 2015) Доступно: <https://zakon.rada.gov.ua/ laws/show/z0703-13> [Дата звернення 17 Квітень 2019] .

Кравець, С. Г., 2018. Вимоги до організаційно-педагогічних умов дистанційного професійного навчання. [online] Освітній простір, 13, с. 154-159. Доступно: <http://lib.iitta.gov.ua/714209/> [Дата звернення 14 Квітень 2019].

Міністерство освіти і науки України (МОН), 2018. Проект конщепиії реалізаиії державної політики у сфері професійної освіти "Сучасна професійна освіта" на період до 2027 року. [online] (Останнє оновлення 10 Жовтень 2018) Доступно: < https://mon.gov.ua/storage/app/media/gromadske-obgovorennya/2018/10/17/1kontseptsiya.docx> [Дата звернення 12 Квітень 2019].

Радкевич, В. О., 2018. Науково-методичне забезпечення модернізації професійної підготовки фахівців: результати наукових досліджень. Професійно-технічна освіта, 3, с. 18-23.

Радкевич, В., Бородієнко, О., Пуховська, Л., Базелюк, Н. та Леу, С., 2018. Модель мережевої взаємодії в розвитку системи професійної освіти і навчання у країнах СС. Науковий вісник Інституту професійно-технічної освіти НАПН України. Професійна педагогіка, 17, с. 123-134. https://doi.org/10.32835/2223-5752.2018.17.123-134.

Радкевич, В.О. та Артюшина, М.В., ред., 2017. Професійно-технічна освіта: інформаційно-аналітичні матеріали за результатами констатувального етапу досліджень. Київ: ІПТО НАПН України.

\section{Translated \& Transliterated}

Bazeliuk, O. V., 2016. Osoblyvosti vyboru system dystantsiinoho navchannia dlia profesiinoi osvity [Peculiarities of LMS selecting for VET]. V: L. I. Shevchuk, ed. Metodychni zasady pidvyshchennia kvalifikatsii pedahohichnykh pratsivnykiv systemy profesiinoi osvity [Methodical bases of vocational teachers in-service training]. [online] Khmelnytskyi: NNTs PTO PK; FOP Melnyk A. A. s. 469-472. Available at: <http://lib.iitta.gov.ua/107095/> [Accessed 17 April 2019], [in Ukrainain].

Bazeliuk, O. V., Kalenskyi, A. A., Kravets, S. H., Maiboroda, L. A. and Myshchyshen, A. V., 2017. Pidhotovka pedahohichnykh pratsivnykiv profesiino-tekhnichnykh navchalnykh zakladiv do dystantsiinoho navchannia kvalifikovanykh robitnykiv [Training of pedagogical workers of vocational schools for distance learning of skilled workers]. Kyiv: IPTO NAPN Ukrainy, [in Ukrainain].

Bazeliuk, O. V., Spirin, O. M., Petrenko, L. M., Kalenskyi, A. A. and Maiboroda, L. A., 2018. Tekhnolohii dystantsiinoho profesiinoho navchannia [Distance learning technologies]. Zhytomyr: Polissia, [in Ukrainain].

Verkhovna Rada Ukrainy. Zakonodavstvo Ukrainy [Verkhovna Rada of Ukraine. Legislation of Ukraine], 2013. Pro zatverdzhennia Polozhennia pro dystantsiine navchannia [Order "On the approval of the Regulations on distance learning" No 466 ] 25.04.2013 № 466. [online] (Ostannie onovlennia 21 Serpen 2015) Dostupno: <https://zakon.rada.gov.ua/laws/ show/z0703-13> [Data zvernennia 17 Kviten 2019], [in Ukrainain].

Kravets, S. H., 2018. Vymohy do orhanizatsiino-pedahohichnykh umov dystantsiinoho profesiinoho navchannia [Requirements for organizational and pedagogical conditions of distance professional education], Osvitnii prostir Ukrainy 
[Educational space of Ukraine], 13, s. 154-159. [online] Available at: <http://lib.iitta.gov.ua/714209/> [Accessed 14 April 2019], [in Ukrainain].

Ministry of Education and Science of Ukraine, 2018. Proekt kontseptsii realizatsii derzhavnoi polityky u sferi profesiinoi osvity "Suchasna profesiina osvita" na period do 2027 roku [Draft of the Conception of realizing the state policy in the sphere of vocational education and training "Modern vocational education and training" for the period up to 2027$].$ [online] (Last update 10 October 2018) Available at: <https://mon.gov.ua/storage/app/media/gromadske-obgovorennya/ 2018/10/17/1kontseptsiya.docx > [Accessed 12 April 2019], [in Ukrainain].

Radkevych, V. O. and Artiushyna, M. V., eds., 2017. Profesiino-tekhnichna osvita: informatsiino-analitychni materialy za rezultatamy konstatuvalnoho etapu doslidzhen [Vocational education and training: information and analytical materials based on the researches' stating stage results]. Kyiv: IPTO NAPN Ukrainy, [in Ukrainain].

Radkevych, V. O., 2018. Naukovo-metodychne zabezpechennia modernizatsii profesiinoi pidhotovky fakhivtsiv: rezultaty naukovykh doslidzhen [Scientific and methodical ensuring the specialists' professional training: research results], Profesiino-tekhnichna osvita [Vocational Education], (3), s. 18-23, [in Ukrainain].

Radkevych, V., Borodiienko, O., Pukhovska, L., Bazeliuk, N. and Leu, S., 2018. Model merezhevoi vzaiemodii v rozvytku systemy profesiinoi osvity i navchannia u krainakh YeS [The networking interaction model in the development of VET in the European Union countries], Naukovyi visnyk Instytutu profesiino-tekhnichnoi osvity NAPN Ukrainy. Profesiina pedahohika [Scientific Herald of the Institute of Vocational Education and Training of the National Academy of Pedagogical Sciences of Ukraine. Vocational pedagogy], (17), s. 123-134. https://doi.org/10.32835/22235752.2018.17.123-134, [in Ukrainain].

УДК 37.018.43:004

\section{Особливості організації цифровізованого освітнього процесу в системах дистанційного навчання}

\section{Олександр Базелюк,}

докторант Інституту професійно-технічної освіти НАПН України

Реферат. У статті автор розглядає особливості організації цифровізованого освітнього процесу в апаратнопрограмному середовищі систем дистанційного навчання в контексті професійної освіти. Автор відзначає складність переходу до четвертого технологічного укладу та зазначає ризики, пов'язані з означеним процесом у професійній освіті. У таких умовах важливим стає вироблення ефективних моделей публічно-приватного партнерства, децентралізації управління та фінансування, а, головне, забезпечення якості професійної освіти. Одним із засобів, здатного забезпечити реалізацію таких завдань та уникнути ризиків у сфері професійної освіти, $є$ використання програмно-апаратних комплексів систем дистанційного навчання (LMS). Водночас освітній процес, що відбувається в середовищі таких систем, стає цифовізованим, що, з одного боку, надає йому додаткових переваг (легкий доступ до навчальних даних незалежно від часу та простору, індивідуалізація освітніх траєкторій учнів, широкі мультимедійні можливості тощо), а з іншого - вимагає вирішення складних завдань зі створення дистанційних курсів. Автор статті зосереджується саме на методиці розробки дистанційних курсів, таким чином, закладу професійної (професійно-технічної) освіти вкрай важливо забезпечити реалізацію п'яти основних їі складових: нормативно-правового забезпечення; фінансового забезпечення; технічного забезпечення; кадрового і навчально-методичного забезпечення. Підкреслюється, що розробка дистанційного курсу стає надзвичайно важливим аспектом здійснення сучасного цифровізованого освітнього процесу. Автором обгрунтовано структуру творчої групи зі створення дистанційних курсів, що складається з: фахівця відповідної галузі; фахівця з дистанційної освіти; технічного спеціаліста (адміністратора системи/програміста дистанційних курсів); дизайнера цифрового контенту. Підкреслено, що є неприпустимим покладати завдання створення дистанційного курсу лише на педагогічного працівника закладу професійної (професійно-технічної) освіти. Водночас процес цифровізації освітнього процесу в конкретному закладі не може бути обмежений лише введенням до нього систем дистанційного навчання.

Ключові слова: професійна освіта, ичифровізація, ичифровізований освітній проиес, ичифрове освітнє середовище, система дистаниійного навчання, дистаниійний курс. 